\title{
Radioimmunoassay of Plasma Aldosterone and its Glinical Application
}

\author{
Toshio OGIHARA, Toshihide YAMAMOTO and Yuichi KUMAHARA \\ Gentral Laboratory for Clinical Investigation, Osaka University Hospital
}

A radioimmunoassay for the determination of plasma aldosterone is described. An antibody against aldosterone 18, 21-disuccinate was supplied by the National Institutes of Health (Bethesda, Md. U.S.A.). One to $2 \mathrm{ml}$ of plasma, with $10000 \mathrm{dpm}{ }^{3} \mathrm{H}$-aldosterone added for recovery calculation, is extracted with dichloromethane. Purification is achieved by paper chromatography (Bush $\mathrm{B}_{5}$ descending system). After overnight incubation at $4^{\circ} \mathrm{C}$, bound and free fractions are separated by dextran-coated charcoal. The average recovery after extraction and purification is greater than $75 \%$. The antibody shows less than $0.6 \%$ cross-reactivity with other plasma corticoids. Nevertheless, aldosterone is undetectable in paper or water blank, plasma of patients after adrenalectomy and plasma enriched with excess cortisol and cortisone. In 10 normal subjects, the plasma aldosterone ranged 2.3-8.5 ng/dl (supine), 8.0-12.0 ng/dl (upright). In 13 patients with primary aldosteronism, it is ranged $16-130 \mathrm{ng} / \mathrm{dl}$ (supine). Technical problems concerning plasma aldosterone measurement by radioimmunoassay are discussed in detail. The clinical significance of measuring plasma aldosterone concentration in lieu of aldosterone secretory rate is discussed as well.

(See pp. 619 628) 


\title{
血中アルドステロンの Radioimmunoassay とその臨床応用
}

\author{
大阪大学医学部附属病院中央臨床検査部 \\ 荻原, 俊男, 山本 智英, 熊原 雄一
}

（昭和47年11月25日受付）

NIH 抗アルドステロン抗体を用いた, 血漿アルドステロンの Radioimmunoassay 法の検討を行い, 臨床応用の可能性を検討した. 血漿アルドステロンはジクロルメタンで抽出, Bush $B_{5}$ による沪紙クロマ トグラフィーで分離後 Radioimmunoassay を行つた。本法による正常範囲は安静臥位 $2.3 \sim 8.5 \mathrm{ng} / \mathrm{d} 1$, 立位 8.0〜 $12 \mathrm{ng} / \mathrm{dl}$ であつた。一方原発性アルドステロン症13例では $16 〜 130 \mathrm{ng} / \mathrm{dl}$ であり，明らかな 高值を示した。アルドステロン分泌率に対し, 血漿アルドステロン濃度測定の意義について考察を加え た.

\section{I 緒言}

ステロイドホルモンの Radioimmunoassay（以下 RIA）は，Lieberman ら²)にるステロイドをハプテ ンとする蛋白結合物に対する抗体を作成するととに端を発し，さらに Abraham ${ }^{2)}$ にる 17 $\beta$-estradiol の RIA の成功に至つた。

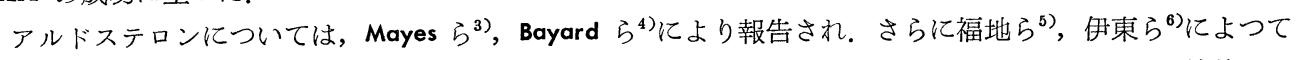
も報告されている。乙れらは Aldosterone 3-oxime 又は Aldosterone 18, 21-disuccinate 亿対する抗体を用 いた血漿アルドステロンの RIA であり, Bayard らは分泌量測定にも応用している7). 最近 Aldosterone$\gamma$-lactone の RIA も報告されており ${ }^{8)}$ ，乙れは尿中アルドステロンの測定に利用されている。アルドステロ ンの RIA は今までの Double isotope derivative dilution 法到に比べれば比較的容易となつたものの, 抗 体が得にくいとと, 少くとも 1 回のクロマトグラフィーによる抽出を必要とするため, 普及するには至つて いない. 我々は NIH より Aldosterone 18, 21-disuccinate 抗体を入手し, アルドステロンの RIA 法を検 討し，乙れを用い血漿アルドステロンの測定を行い，その意義とついて考察を加えた。

\section{II 材料及び方法}

\section{1. 試薬, 器具}

メタノール, ベンゼン, ジクロルメタン, クロロフォルムは spectro grade 用いた. 結晶Dアルドステロ ンは Sigma 社のものを使用し, 島津微量天秤により計量し以下, 計量フラスコにより稀橎を行い標準溶液 を準備した。標識アルドステロン $\left(1,2^{3} \mathrm{H}\right.$-Aldosterone) は Nuclear Chicago 社製で S.A. $50 \mathrm{mCi} / \mathrm{mM}$ で あり, Bush $\mathrm{B}_{5}$ 系で精製, $-20^{\circ} \mathrm{C}$ で保存したものを使用した. Bovine Serum Albumin（以下 BSA）は Armour 社製 Fraction V を用いた。沪紙クロマトグラフィーはあらかじめメタノールで $2 \sim 3$ 日間洗滌し た Whatman No. 1 を用いて行つた. RIA, 抽出に用いるガラス器具は全て重クロム硫酸に一昼夜浸した後, 純水で洗涤，さらにメタノールで洗滌したものを使用した。

\section{2. 血獎アルドステロン抽出}

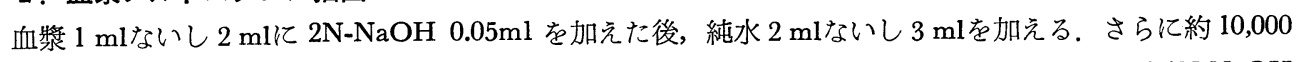

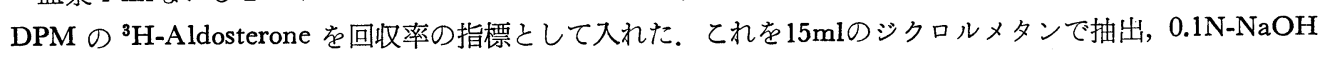


$2 \mathrm{ml}$ で洗涤, さらに純水 $2 \mathrm{ml}$ で 1 回洗滌した後, ジクロルメン層を正確に $10 \mathrm{ml}$ とり, 尖型試験管に入れ た。 乙れを蒸発乾固し，0.1 0.2mlの1：1メタノール：クロロフォルム液で溶解，Bush $\mathrm{B}_{5}$ 系（ベンゼ ン：メタノール：水 $2 ： 1 ： 1 ）$ でアルドステロンを分離した。沪紙クロマトグラフィーは 2 時間飽和, 12時間展開する。イサチン色素を同時に 1 条併行させアルドステロン部位の推定に使つた。すなおちイサチ ン相当部位の上下 $5 \mathrm{~cm}$, 合計 $10 \mathrm{~cm}$ を切りとりさらにアクチグラム (Packard Radiochromatogram scanner Model 7201) にかけ，アルドステロン部位を確認し，ての部分 $3 \mathrm{~cm}$ を切りとり，メタノール $3 \mathrm{ml} 1$ 時 間浸し溶出した。溶出液 $3 \mathrm{ml}$ の内， $0.5 \mathrm{ml}$ を Bray 溶液化て液体シンチレーションカウンター (Nuclear

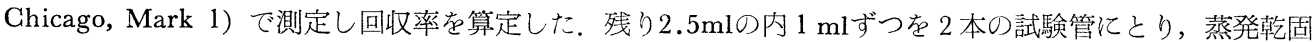
し，以下の測定に供した。

\section{RIA}

各試験管に標準アルドステロン (10pg/tube から $1000 \mathrm{pg} / \mathrm{tube}$ まで各濃度) 又はサンプルを入れ蒸発乾 固した後, 一定量の ${ }^{3} \mathrm{H}-\mathrm{Ald}$ osterone（約 10000DPM）を加えた。さらに標準曲線用試験管には，被験血漿 に先に添加した回収率補正用の ${ }^{3} \mathrm{H}$-Aldosterone の残量の平均値に相当する ${ }^{3} \mathrm{H}$-Aldosterone を加光，標準 曲線用試験管及びサンプルの各試験管に含まれる ${ }^{3} \mathrm{H}-\mathrm{Ald}$ osterone 量がほぼ等量になるようにした，全試験 管を蒸発乾固，50万倍稀釈抗アルドステロン抗体を含む $1.5 \%$ BSA-硼酸緩衝液 $\mathrm{pH} 8.0,1 \mathrm{ml}$ を加えた。 $37^{\circ} \mathrm{C} 5$ 分間 incubation, 次いで $4{ }^{\circ} \mathrm{C}, 12$ 時間の incubation を行つた，抗原抗体結合型一非結合型分離 (B-F 分離) は Dextran-coated charcoal 液 (Dextran $70250 \mathrm{mg}$, Norit A neutral charcoal $250 \mathrm{mg}$ を硼酸緩衝液 $100 \mathrm{ml}$ 亿加えたもの） $1 \mathrm{ml}$ を加光10秒 間 Vortex mixer で振湯，5分間 $3000 \mathrm{cpm}$ で泠凍 遠沈し, 上清 $0.5 \mathrm{ml}$ Bray 溶液 $10 \mathrm{ml}$ 亿入れ放射能 を測定した．計算は加えた総放射能(T)に対する抗体 結合放射能(B)の此・B / T \%で表わした。 各サンプ ルのアルドステロン濃度は次式で求められる.

〔骠潐曲線より読み取つた濃度 $\mathrm{pg}$ 〕 $\times 3 \times \frac{15}{10} \times(1$ /抽出サンプルの $\mathrm{ml}) \times(100 /$ 回収率\% $)=\mathrm{pg} / \mathrm{ml}$ 抽 出過程及び RIA 法の概略を Fig. 1 亿示した。

\section{4. 血獎レニン活性測定}

ダイナボット社製レニン活性測定用キットを用い， アンギオテンシンIの $\mathrm{RIA}^{10)}$ にり測定した。

\section{5. 対 象}

原発性アルドステロン症患者は, 手術確認例及び 臨床的に診断確定されたものである. 正常対照群と しては主としてドック入院患者で血圧正常で異常所 見のないものである。採血は安静臥位 1 時間後, 及 び立位 4 時間の 2 点で行つた。

\section{IIII結果}

\section{RIA の条件}

Bray 溶液を用いる放射能計数効率は約 $12 \%$ であ り, サンプル間の消光の程度はほぼ一定している為,

Fig. 1. Proceidure of plasma aldosterone measurement by radioimmunoassay

Measurement methods for Plasma Aldosterone

Plasma Sample $2 \mathrm{~m} \ell$ or $1 \mathrm{ml}$

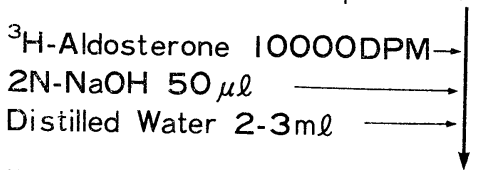

Extraction with $\mathrm{CH}_{2} \mathrm{Cl}_{2}(15 \mathrm{ml})$ -wash

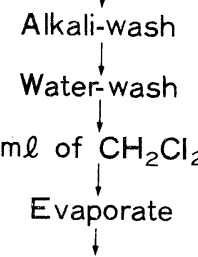

Paperchromatography (Bush $B_{5}$ )

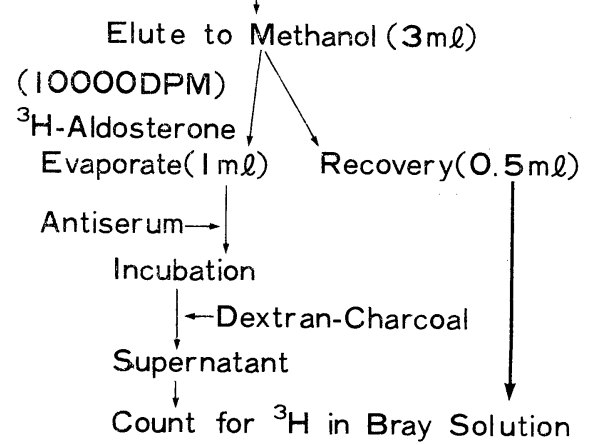


消光の補正は RIA における放射能測定時には行わなかつた。

a) 硼酸緩衝液の蛋白濃度

BSA の濃度は Lot. でとに最も理想的濃度を決めた。0.5から $5.0 \mathrm{~g} / \mathrm{dl}$ の各段階の緩衝液を作成し，標準 物質非添加時のB / T \% (Bo \%) を求め，乙れが最高となる濃度を以下の測定に用いた。 Lot No. H37706 の結果は Fig. 2 亿示す通りで，ての場合には $1.5 \mathrm{~g} / \mathrm{d}$ の濃度で最高のBo\%を示した。

b ) 抗体稀釈

抗体稀勫を 10 万倍, 25 万倍, 50 万倍の 3 系列で RIA を行つた，Fig. 3 亿示す如く， 50 万倍稀勫で最も感 度の良い標準曲線が得られた。 以後の測定は50万倍稀釈抗体を用いて行つた。

c) ${ }^{3} \mathrm{H}$-Aldosterone 量

RIA 飞加光る総放射能の量を約 10,000DPM, 20,000DPM, 30,000DPM ひ3 系列を用い, 50万倍稀釈抗 体で検討した結果, Fig. 4 亿示す如く, 約 10,000DPM で最も良好な標準曲線が描けた。 b ）及びc ）の条 件により，最小測定感度は $10 \mathrm{pg} / \mathrm{tube}$ であつた。

d) incubation の条件

incubation を以下の 3 方法で検討した.

Fig. 2. Optimal concentration of bovine serum albumin for radioimmunoassay

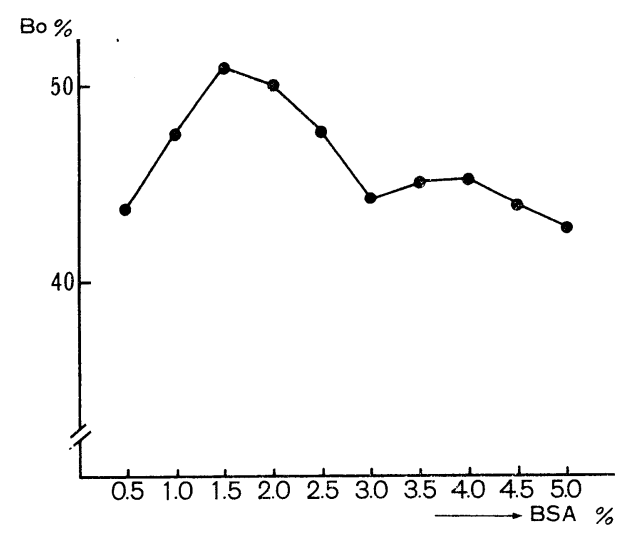

Fig. 4. Standard curve using different doses of tritiated aldosterone

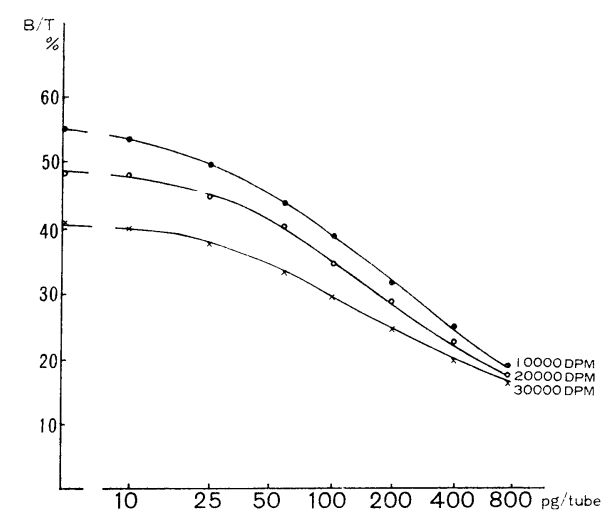

Fig. 3. Standard curve using different dilution of antibody

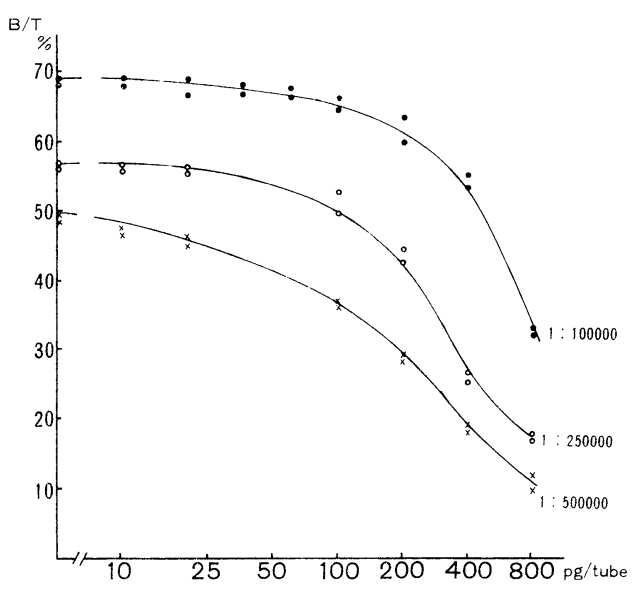

Fig. 5. Standard curve under different incubation condition

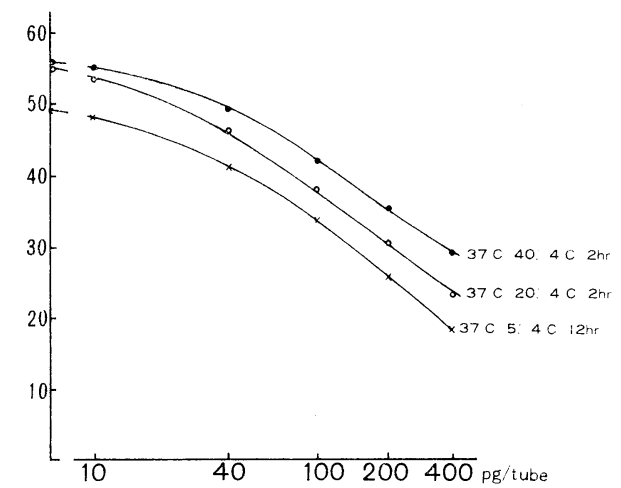


i) $37^{\circ} \mathrm{C} 20$ 分後, $4{ }^{\circ} \mathrm{C} 2$ 時間, ii) $37^{\circ} \mathrm{C} 5$ 分後, $4{ }^{\circ} \mathrm{C} 12$ 時間， iii) $37^{\circ} \mathrm{C} 40$ 分後, $4{ }^{\circ} \mathrm{C} 12$ 時間. i) の場合Fig. 5 亿示す如く，ii）に比し全体に Bound を上昇させたが，感度においては ii）とほぼ同様であつた。iii) のBoはi）とほぼ同様であつたが感度は不良となつた。

e) B-F 分離

Dextran-coated charcoal (以下 DGG) によるB-F 分離と Bayard ら ${ }^{4)}$ の方法に準じた Florisil による分 離とを比較した。DCG 法は Florisil 法に比し全体に Bound が高く，最小測定感度はやや不良であつた。 (Fig. 6)

\section{f ）交叉反灾}

他のステロイドとの交叉性は Fig. 7 及び Table 1 亿示す如くであり, Cortisol, Cortisone はその血中 濃度から考えてての程度の交叉でも抽出が必要であ る. Spironolactone とは $1 \mathrm{mg}$ まで交叉性を示さな かつた。

Fig. 6. B-F separation, a comparison with DCG method and Florisil method

\section{2. 沪紙クロマトグラフィー}

Fig. 8 亿 Bush $B_{5}$ 系で 6 時間展開した時の各種 ステロイドの Rf 值を示した。 なおイサチン色素の Rf はアルドステロンとほとんど一致していた。実 際の測定にあたつては Gortisol, Aldosterone, Gortisone の分離をよくするために12時間展開させるこ とにより 3 者は互に $3 \mathrm{~cm}$ 以上離れた. Fig. 9 亿示 す如く, イサチン相当部位を中心に $10 \mathrm{~cm}$ 程切り,

アクチグラムによりアルドステロン部位を同定した．

Fig. 10 はアクチグラムの一部である.

\section{3. 回収率}

沪紙クロマトグラフィー直前までの回収率は平均 95\%であつた，沪紙クロマトグラフィー後，メタ， 一ル溶出までの抽出段際における最約的回収率は78 \%であつた。

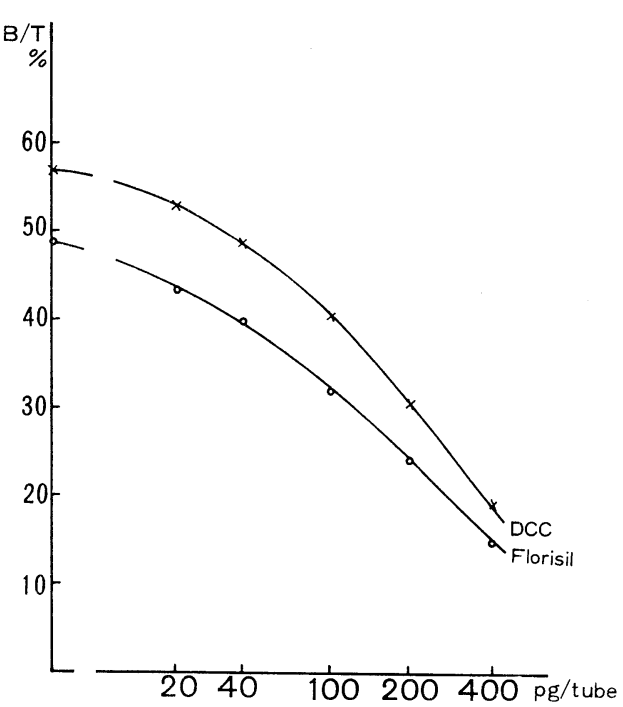

Fig. 7. Cross reactivity with other corticosteroids

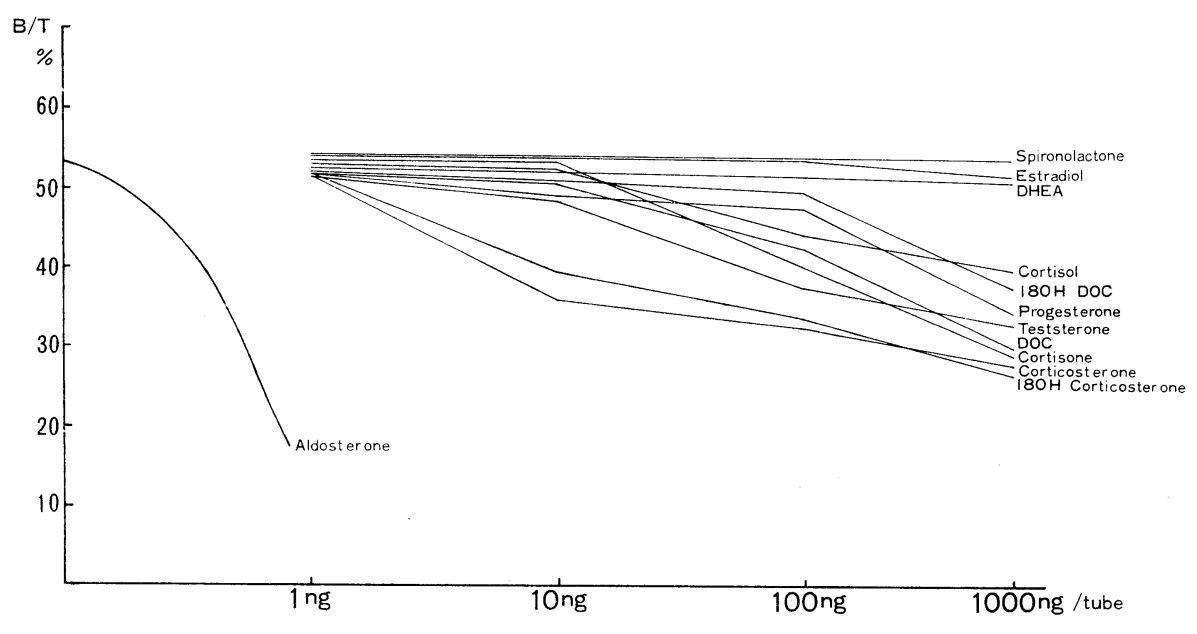




\section{4.ブランク值及び副腎摘除患者測定值}

全過程を純水で行つた場合の Water blank は感度以下であつた。両側副腎摘除症例及びアジソン病でコ 一チゾン補傥療法中の患者 2 名の血漿測定時はいずれも感度以下を示した．純水に Cortisone 20ng., Corti-

Table 1. Cross reactivity with other steroids The $\%$ cross reaction was calculated as follows : If $\mathrm{X}$ represents the $\mathrm{pg}$ of aldosterone required to displace $50 \%$ of the ${ }^{3} \mathrm{H}$-aldosterone bound to the antibody and $\mathrm{Y}$ equals the pg of steroid $\mathrm{S}$ required to displace $50 \%$ of $3 \mathrm{H}$-aldosterone bound to the antibody, then the $\%$ cross reaction of steroid $S$ is $(\mathrm{X} / \mathrm{Y}) \mathrm{x}$ 100.

\begin{tabular}{l|c}
\hline \multicolumn{1}{c|}{ Steroid } & \% cross reaction \\
\hline 18-hydroxycorticosterone & 0.6 \\
Cortisol & 0.3 \\
Corticosterone & 0.1 \\
Cortisone & 0.08 \\
Testosterone & 0.08 \\
Deoxycorticosterone & 0.03 \\
Progesterone & 0.03 \\
18-hydroxy DOG & 0.003 \\
DHEA & $<0.001$ \\
Estradiol & $<0.001$ \\
Spironolactone & $<0.001$ \\
\hline
\end{tabular}

Fig. 8. $\mathrm{Rf}$ value of corticosteroids in Bush $B_{5}$ paperchromatography

Bush $\mathrm{B}_{5}$ Paper Chromatography

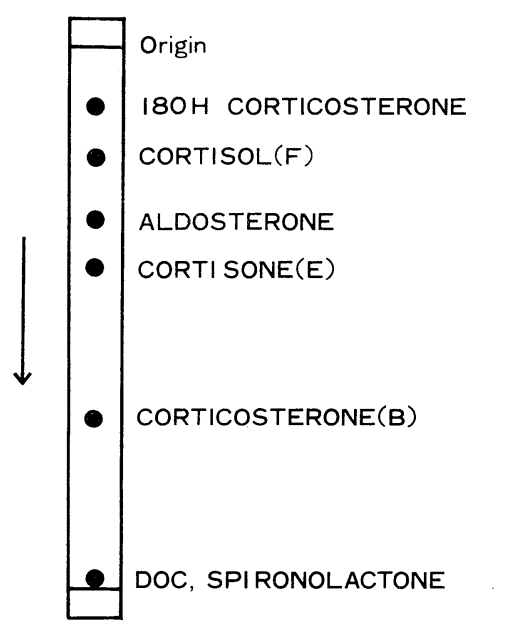

Rf

0.10

0.20

0.35

0.41

0.77

1.00 sol 100ng, を添加した溶解液の測定值は感度以下で あつた。 またプール血清（アルドステロン濃度 95 pg/ml) 飞 Cortisone 20ng., Cortisol 100ng. を添 加した場合の測定值は $90 \mathrm{pg} / \mathrm{ml}$ であり，なんら影 響がみられなかつた。

5 ) Accuracy

プール血清に既知量のアルドステロン $50 \mathrm{pg}, 100$ pg, 200pg, 250pg, 500pg を添加して測定した場合 の回収率は各々 $100 \% ， 96.9 \% ， 93.5 \% ， 96.0 \%$ ， 97.6\%であり Accuracy は Y (pg of Aldosterone measured $)=0.965 \mathrm{X}$ (Aldosterone expected) -2.75

Fig. 9. Schema of paperchromatography

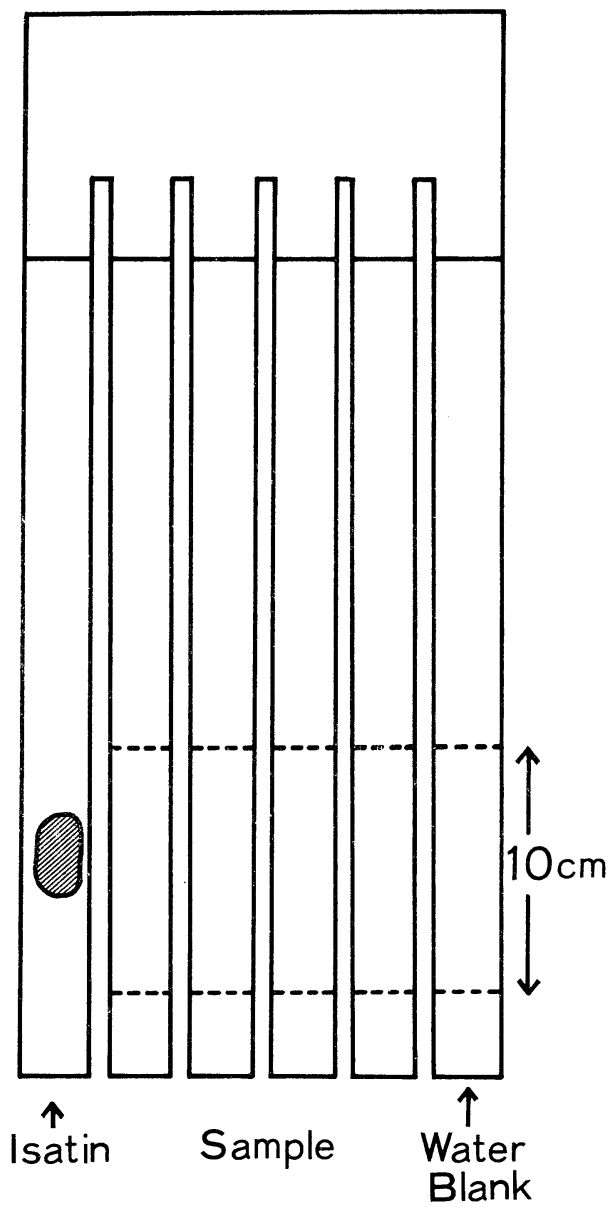


Fig. 10. Schema of actigram obtained by Bush $B_{5}$ paperchromatography Linear Range 3K

Time Constant 3 seconds
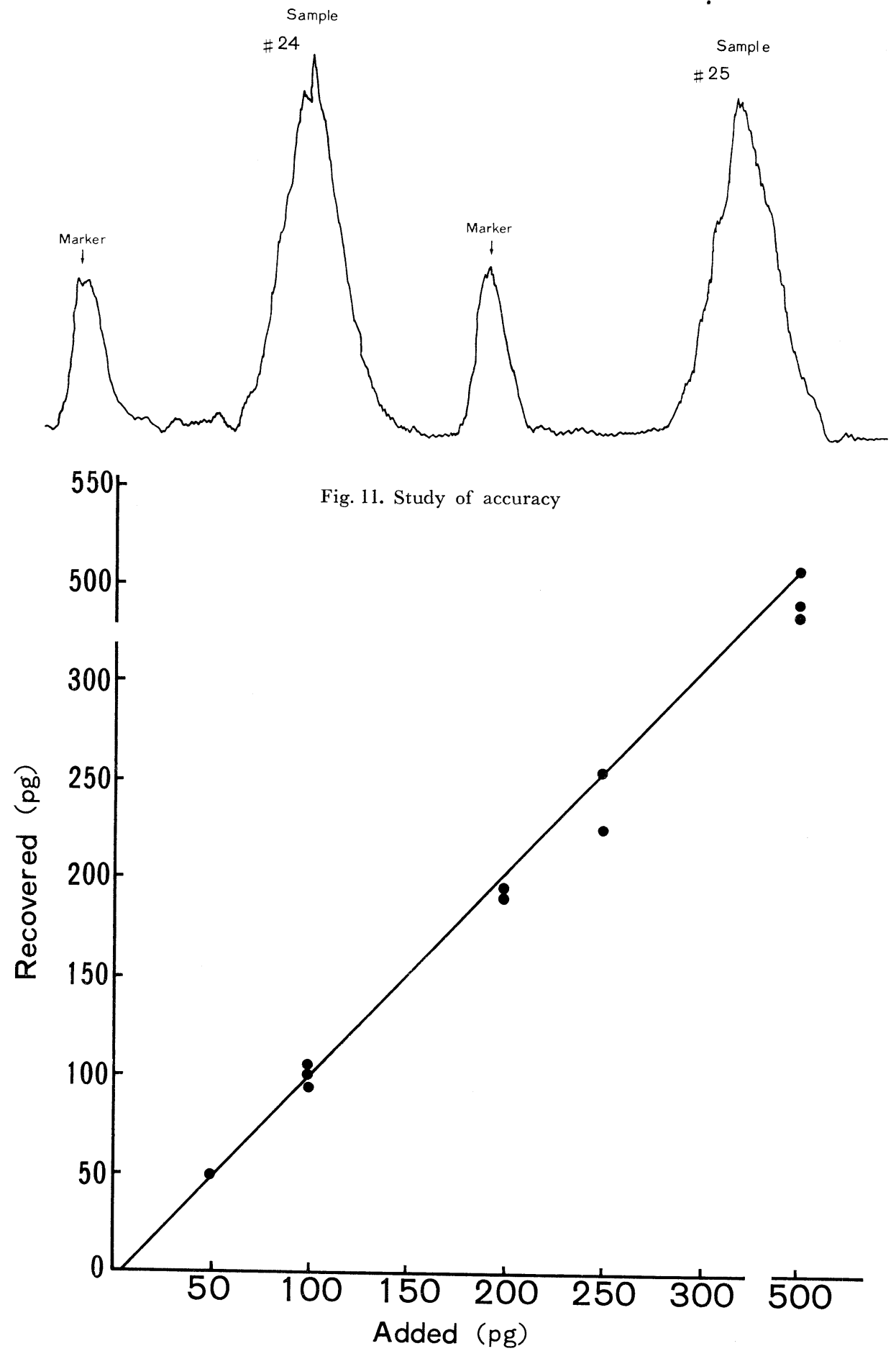

第 49 巻 第 3 号 
と良好な結果を示した。 (Fig. 11)

6 ) Reproducibility, Variability

本測定法による再現性及び同一測定内の Variability は Table 2, 3 に示す如く，良好な結果を示し，い

Table 3. Intra-assay variability

\begin{tabular}{c|c|c|c}
\hline \hline Sample & \multicolumn{3}{|c}{$\mathrm{pg} / \mathrm{ml}$} \\
\hline No. 8 & 17.5 & 17.5 & 21.4 \\
No. 9 & 100 & 127 & 120 \\
No. 10 & 100 & 109 & \\
No. 11 & 104 & 123 & \\
No. 12 & 90 & 100 & \\
\hline
\end{tabular}

Table 2. Reproducibility of assay

\begin{tabular}{c|c|c}
\hline Sample & $\begin{array}{c}\text { First assay } \\
(\mathrm{pg} / \mathrm{ml})\end{array}$ & $\begin{array}{c}\text { Second assay } \\
(\mathrm{pg} / \mathrm{ml})\end{array}$ \\
\hline No. 1 & 102 & 107 \\
No. 2 & 550 & 570 \\
No. 3 & 325 & 362 \\
No. 4 & 285 & 296 \\
No. 5 & 563 & 638 \\
No. 6 & 21 & 18 \\
No. 7 & 68 & 50 \\
\hline
\end{tabular}

Fig. 12. Plasma aldosterone level in change of posture

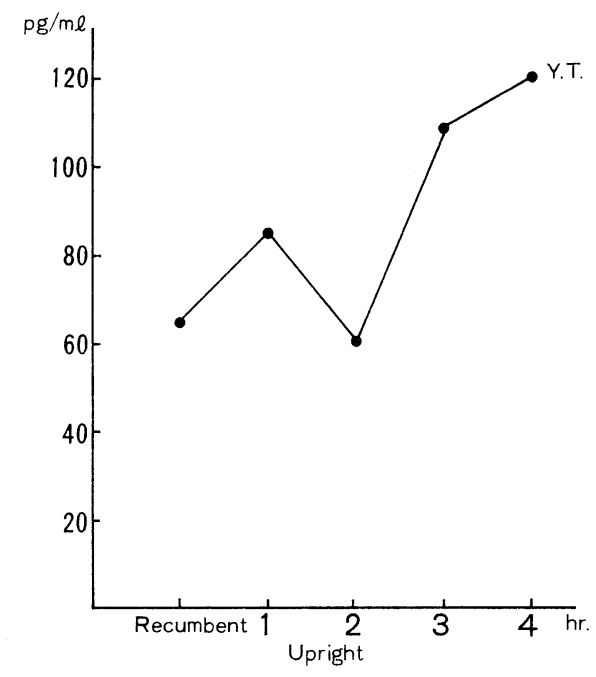

Fig. 13. Plasma renin activity and aldosterone in normals and patients with primary aldosteronism

Plasma Renin Activity

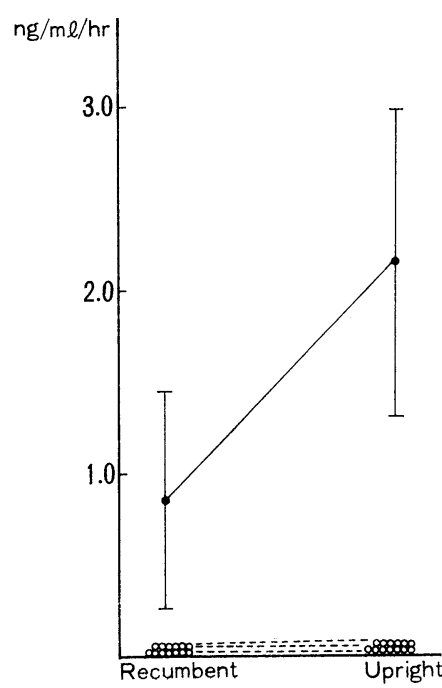

Plasma Aldosterone

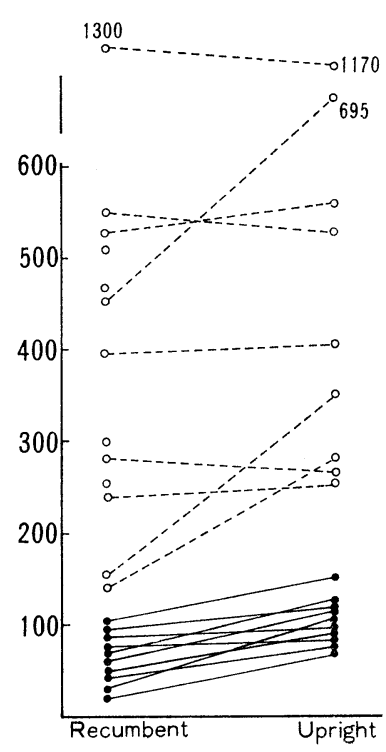


ずれも変動係数 $10 \%$ 前後であつた。

7 ) 測定值

臥位より立位に体位を変換させ， 1 時間毎に測定した血漿アルドステロンの変化をみると，Fig. 12亿示す 例の如く， $3 ， 4$ 時間で上昇の傾向を示した．我々は一般検査としては安静卧位 1 時間後及び立位負荷 4 時 間の 2 点で測定している.

常食（食塩捠取量 $7 \sim 10 \mathrm{~g} /$ 日）下の健常人の正常値は臥位 $23 \sim 85 \mathrm{pg} / \mathrm{ml} \quad(51.1 \pm 18 \mathrm{pg} / \mathrm{ml}$, mean \pm S.D., 10例）立位 $80 \sim 120 \mathrm{pg} / \mathrm{ml}(102 \pm 13 \mathrm{pg} / \mathrm{ml} ， 10$ 例 $)$ であつた。一方原発性アルドステロン症患者 13 例では卧 位 $140 \sim 1570 \mathrm{pg} / \mathrm{ml}$ ，立位 $240 \sim 1170 \mathrm{pg} / \mathrm{ml}$ の高值を示した，健常者及，原発性アルドステロン症患者の血 漿レニン活性及びアルドステロン值の関係を Fig. 13 亿示した.

原発性アルドステロン症で手術的に腺腫 の確認された患者 1 例 の副腎静脈血アルドステロン值は患側で $6750 \mathrm{pg} / \mathrm{ml}$, 対側 $818 \mathrm{pg} / \mathrm{ml}$ 末梢血では臥位 $427 \mathrm{pg} / \mathrm{ml}$, 立位 $695 \mathrm{pg} / \mathrm{ml}$ であつた. Bartter 症候群の疑われ た 1 例では臥位 $270 \mathrm{pg} / \mathrm{ml}$ ，立位 $270 \mathrm{pg} / \mathrm{ml}$ を走した。 との症例にアンギオテンシン II 点滴静注したとき のアルドステロン值は前值 $161 \mathrm{pg} / \mathrm{ml}$ から $378 \mathrm{pg} / \mathrm{ml}$ に上昇したが，ノルアドレナリンの静注では $166 \mathrm{pg} /$ $\mathrm{ml}$ と不変であつた。 さらに本症例で 3 日前の無塩食と $80 \mathrm{mg}$ のフロセマイド投与したときのアルドステロ ン值は臥位 $390 \mathrm{pg} / \mathrm{ml}$ ，立位 $831 \mathrm{pg} / \mathrm{ml}$ と上昇した。 1 例の浮腫を併う心不全患者では $987 \mathrm{pg} / \mathrm{ml}$ の高值を 示した。

\section{IV 考按}

NIH より入手した抗アルドステロン抗体（ 088）を用いた血漿アルドステロンの測定法の検討を行つた.

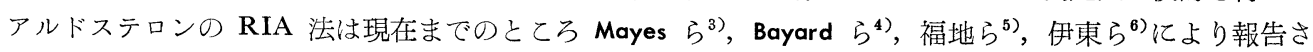
れており，てれらは Aldosterone 3-oxime 又は Aldosterone 18, 21-disuccinate に対する抗体を用いたも のであり，我々の用いた NIN の抗体も Aldosterone 18,21-disuccinate に対する抗体である.さらに最近 Aldosterone $\gamma$-lactone に対する抗体も報告されている.

本抗体は Cortisol, Cortisone と各々 $0.3,0.08 \%$ 程度の交叉性を示すため, 血漿よりアルドステロンを 抽出後, RIA を行う必要がある。抽出には Silica gel column を用いるもの を用いるもの等が報告されている，また後者にはアルドステロンの部位確認のため， ${ }^{3} \mathrm{H}-\mathrm{Ald}$ dosterone t卜 レーサーとして用いアクチグラムによるアルドステロンの同定を行うもの ${ }^{3)}$ や, サンプルと平行して展開し た標準アルドステロンの紫外部吸収部位よりサンプルのアルドステロンの位置を推定する方法がある゙. 我 々は Bush $\mathrm{B}_{5}$ 系を用い12時間展開分離し，メタノールによる抽出を行つているが，同一タンク内の各条に おけるアルドステロン部位は必ずしも一定しない場合があるので，てのためイサチン相当部位を $10 \mathrm{~cm}$ 切り 出し，さらにアクチグラムで同定する方法をとつている，ての方法により各サンプルの回収率のバラッキを 10\%以内におさえるととができた。

RIA については加える放射能の宣多により標準曲線の位置は上下に変化する (Fig. 4), 従つて Mayes ら ${ }^{3)}$ が行つているようにサンプルに抽出以前に大量の ${ }^{3} \mathrm{H}-\mathrm{Aldos}$ terone を加えておき，乙の ${ }^{3} \mathrm{H}-\mathrm{Ald}$ dosterone te RIA に利用する場合，サンプルのアルドステロンの抽出の回収率のバラツキにより RIA における総放射 能の量が変化するととになり，何んらかの補正が必要となる。我々の用いた方法では RIA 実施の際，サン プル，標準曲線共に 10,000DPM の ${ }^{3} \mathrm{H}-$ Aldosterone を用い，さらに標準曲線の試験管には各サンプル残留 している ${ }^{3} \mathrm{H}-$ Aldosterone の平均量を加えるととにより上記の補正の必要をなくしている，ての場合 RIA に用いる総放射能の量がやや大量になる為，感度が若干低下するようである。

RIA の incubation の条件として Mayes $ら^{3)}$ は $4^{\circ} \mathrm{C} 5$ 時間, Bayard $\zeta^{4)}$ は $37^{\circ} \mathrm{C} 20$ 分, 福地 $\zeta^{5)} は 4^{\circ} \mathrm{C} 16$ 時間で行つており, 伊東ら ${ }^{6)}$ は $40^{\circ} \mathrm{C} 5$ 分後 $6{ }^{\circ} \mathrm{C} 1$ 時間の方法を報告している.メタノールに溶出されたアル ドステロンを試験管で蒸発乾固を行つた後, 抗体を含む緩衝液を加光た場合, $37^{\circ} \mathrm{C}$ 亿加温するととによりガ ラス壁に附着したアルドステロンの溶出が容易になると思われる ${ }^{11)}$. しかし $37^{\circ} \mathrm{C} て ゙ 20$ 分以上 incubate する 
場合 RIA そのものの感受はかえつて低下するような結果を得たので我々は $37^{\circ} \mathrm{C} 5$ 分間で行なつている.

B-F 分離に関しては飽和硫酸アンモニウムを用いるもの ${ }^{3)}$, Florisil を用いるもの文，などのほか Sephadex G25 のカラムを用いる方法も報告されている12)，我々は Florisil， DGC 法の 2 者を検討した結果，い ずれも满足すべき結果を得たが，DCG 法は Florisil 法に比しやや感度が低下するが，操作は非常に簡単で ある.

福地らする述べているように微量のアルドステロンの測定には用いる器具の洗桬は極めて重要であり, 不 充分な洗桬ではブランク值が高くなる傾向がある。我々は使用するガラス器具はすべて重クロム硫酸により 洗條した後, メタノールによる洗涤を行つた。 またクロマトグラフィーに用いる沪紙はあらかじめメタノー ルによる洗涤を行い用いた。 てのようにして Water Blank は感度以下であり，さらにコーチゾン補償療法 を受けている副腎摘除及びアジンン病患者の測定值は感度以下であつた。さらに Cortisol, Cortisone を純水, プール血清に添加した場合も何んら影響がみられず，乙れらより本測定法ではアルドステロン以外の物質の 影響はほとんどないととがわかる。

本測定法による最小測定感度は絶対量としては $10 \mathrm{pg}$ であり，1 $\mathrm{ml}$ の血漿サンプルより測定する場合に は抽出操作のため約 $30 \mathrm{pg} / \mathrm{ml}$ であつた.

測定内又は測定間の変動，アルドステロン添加サンプルょり求めた測定の正確度については満足すべき結 果であつた．以上の結果から我々の用いている方法はアルドステロン測定法としての諸条件を満足している と考えられる.

普通食摂取を行つている健常者において本法を用いて測定した血漿アルドステロン值は臥位 $5.1 \pm 0.19 \mathrm{ng} /$ $\mathrm{d} 1$, 立位 $10.2 \pm 1.3 \mathrm{ng} / \mathrm{dl}$ であり，乙れらの值は同じく RIA で測定された諸家の成績，すなわち Bayard ら $1.35 \pm 1.0512 .2 \pm 7.4 \mathrm{ng} / \mathrm{dl}$ (各々臥位, 立位) ${ }^{4}$, Mayes ら 7.4 $\pm 4.2,13.3 \pm 8.9 \mathrm{ng} / \mathrm{dl}^{3}$ ), 福地ら $2.6 \sim 13.0 \mathrm{ng} / \mathrm{dl}^{5)}$ とほぼ同様であつた。

血漿アルドステロン濃度は体位，食塩摂取量で著しく変動する。また健常者においても減塩，フロセマイ ド負荷により 30〜40ng/dl までの上昇がみられる，ての他 Katz らにより女性における月経周期の黄体期で は卵胞期より高値であることが報告されている11)。またアルドステロンの血中濃度は必ずしも副腎よりの分 泌率をそのまま反映するものでなく，主として肝によると考えられる metabolic clearance rate によつても 変動するといれている ${ }^{13)}$. しかし二つの異なる病的状態の比較の場合, 以上に述べた本位, 食塩摂取量, 月 経周期など一定の条件の下で血漿アルドステロン濃度の測定が行われるならば，血中濃度の測定により，副 憼よりの分泌率を間接的に反映した量を測定しうるものと考えられる.

臨床応用の一つは原発性アルドステロン症の診断であるが, 普通食拱取の条件下で採血された原発性アル ドステロン症13例では 16〜130ng/dl (安静臥位) であり，明らかに健常者との間に差異がみられた，次に左 右の副腎静脈血中のアルドステロン濃度を測定するととにより原発生アルドステロン症の部位決定あるいは 両側過形成の診断に資すると考元られる ${ }^{14)}$. 我々も 1 例手術前に左右副腎静脈血で測定, その濃度の左右差 は手術所見と一致した。また Bartter 症候群における低カりウム血性アルカロージス, 四肢マヒは高レニン 血症による高アルドステロン症の結果と説明されているが，我々の経験した一例でも血漿アルドステロン16 〜27ng/dl (臥位) の高值がみられた.

以上 RIA による血漿アルドステロン測定は分泌量測定の際のようにアイソトープを人体に投与するとと なく, 少量の血漿サンプルからの測定が可能であり, これにより血中レベルの経時的測定も容易となつた。 今後, 本法を用いるととにより, レニンーアンギオテンシン一アルドステロン系などの生理, 病態生理に関 する多くの有用な情報が得られることが期待される.

本論文の要旨は第19回臨床病理学会総会 (1972, 久留米) 亿扔いて発表した。レニン活性測定キットの提 供をいただいたダイナボット社及び抗アルドステロン抗体の提供をいただいた NIH に感謝の意を表します。 


\section{文献}

1) Lieberman, S., B·F. Erlanger, S.M. Beiser, and F. Agate : Rec. Prog. Hormone Res., 15 : 165, (1959).

2) Abraham, G.T. : J. Clin. Endocr., 29 : 866, (1969).

3) Mayes, D., S. Furuyama, D.C. Kem, and C.A. Nugent : J. Clin. Endocr., $30: 682$, (1970).

4) Bayard, F., I.Z. Beitins, A. Kowarski, and G.J. Migeon : J. Clin. Endocr., $31: 1$, (1970).

5）福地総逸, 勝島一郎, 竹内孝彦 : ホルモン と臨床, $19: 945,(1971)$.

6) Ito, T., J. Woo, R. Haning, and R. Horton : J. Clin. Endocr., $34: 106,(1972)$. 7) Bayard, F., I.Z. Beitins, A. Kowarski, and G.J. Migeon : J. Clin. Endocr., $21: 507,(1970)$. 8) Farmer, R.W., W.G. Roup, E.D. Pellizari, and L.F. Fabre Jr., J. Glin. Endocr., $34: 18,(1972)$. 9) Bayard, F., A. Kowarski, V.V. Weldon, and C.J. Migeon : J. Lab. Glin. Med., 75 : 347, (1970). 10）荻原俊男, 山本智英, 土井 啓, 熊原雄一: 第10回 Radioimmunoassay 研究会発表 (昭和47年, 京都)

11）荻原俊男, 山本智英, 未発表データ 伊東貞三: 最新医学, 27 826, (1972). 13) Gray, G.H., and A.L. Bacharach : Hormones in Blood, Vol. II, 2nd ed. (1967), 414, Academic Press, London and New York. 14) Melby, J.G., Spark, R. F., Dale, S.L., Egdahl, and P.C. Kahn : New Eng. J. Med., 277 : 1050, (1967). 